\title{
A Review on Additive Manufacturing Techniques in Medical Applications
}

\author{
R. Dinesh Babu ${ }^{1,2 *}$, D. Devaprakasam ${ }^{1,3}$ \\ ${ }^{1}$ School of Mechanical and Building Sciences, VIT University, Chennai Campus, Chennai - 600127, India \\ ${ }^{2}$ Department of Mechanical Engineering, Rajiv Gandhi College of Engineering and Technology (RGCET), \\ Puducherry - 607402, India \\ 3InCUBE-EngSciRes RandD, Alpha Academy Tech, Udumalpet, Coimbatore - 642126, India
}

ABSTRACT: In today's technology, the usage of Additive Manufacturing (AM) in the medical field is rapidly growing everywhere around the world. Additive Manufacturing technology makes easier production of dental and orthopedic parts in which the geometry of the product varies among patients. In this review, we briefly discussed the materials and methods involved in AM used to fabricate a prosthesis in dentistry and orthopedics. Polymeric, metallic and ceramic-based materials processed via AM plays a real-time application in medical sciences. We discussed in detail about the list of AM processes used for fabrications of implants in dentistry and orthopedics. We also included the characterization techniques used in additively manufactured nanocomposites and difficulties in testing. The paper gives the state-of-the-art study of Additive Manufacturing in medical implant synthesis using polymeric nanocomposites. Multidisciplinary research is required to fully utilize the $\mathrm{AM}$ methods for biomedical applications.

KEYWORDS: Additive Manufacturing, 3D Printing, Biomaterial implants, Hierarchical nanocomposite, Medical implants https://doi.org/10.29294/IJASE.5.3.2019.988-997 (C) 2019 Mahendrapublications.com, All rights reserved

\section{INTRODUCTION}

The concept of AM was found few decades ago [1]. The applications of additively manufactured scaffolds and implants in the field of dentistry and orthopedics are limited to a few types of polymeric, ceramic and metallic biomaterials [2,3]. In this review, it is discussed about various process used to manufacture scaffolds and implants by the processes of additive manufacturing technology such as Vat Polymerization, powder bed fusion, binder jetting (3D Printing), material jetting, sheet lamination and direct energy deposition. The market of 3D Printing (3DP) is rapidly growing in the field of health sciences. Numerous business investigators, consultancy organizations and financial institutions have found the 3D printing industry and market is growing rapidly [4]. It is predicted that the worldwide market for 3D Printing to reach USD 2.86 billion by the year 2025 [5]. In the current decade in India the applications of AM are raising. Many multinational companies highly investing in India to start AM technology for the medical industry.

The human bone is made of calcium phosphate mineral which acts as a hard layer and collagen acts as a soft layer [6].It is a hierarchically structured material in nature $[7,8]$. Synthesizing hierarchically structured materials by conventional methods are highly difficult [9]. AM techniques eliminate this difficulty in synthesizing. Many biomaterials are available in the market for practical applications in dentistry and orthopedics $[10,11]$.However, the life span, reliability, bio-compatible and mechanical properties of the implant material is not up to the expectation $[12,13]$. Number of researches are being carried out to find the out the most reliable, high strength and long-lasting material [14]. AM technique is nowadays used in orthopaedic and dentistry for manufacturing hierarchically structured materials which are similar to naturalbone and dental structure $[15,16]$. From nano to micro to macro materials can be used together to form a hierarchically structured material as bio-nanocomposite implants in AM techniques [17-19]. Patient specific implant materials can be made by using digital imaging and communications in medicine (DICOM) like Computed Tomography (CT) scan and Magnetic Resonance Imaging (MRI) scan data [20]. Then the scanned data can be converted to 3D model using software's. The 3D model file can be computer aided design (CAD) file or a stereolithography STL file. The CAD or STL file is then corrected with topological and surface smoothness to make is easier for manufacturing it in the 3D Printer [21].The method of using 3D Printing technology differs from material to material with respect to areas of specific applications.

Additive manufacturing also gives us a way to print customized polypills with multiple combinations of medicine for diabetic and hypertensive patients. Polypill that contains a different set of medicine combinations in a single pill to treat a patient having diabetic and hypertensive patients. In Medicine practice, rehearsal of the surgery can be done by using additive manufacturing by 3D printing the model of a patient's surgical site. Using 3D printed models, it is possible to plan for a surgery. This will reduce the time of operation; can save blood loss and also patient can recover faster due to less sutures. Each and every patient to patient the size of prosthetic will vary. Patient specific implants can be made easily by additive manufacturing [22]. There is no need of

*Corresponding Author: rdineshbabupdy@gmail.com

Received: 05.01.2019 Accepted: 18.02.2019 Published on: 27.02.2019

Dinesh Babu \& Devaprakasam 
preparing the bone (cutting, removing and grinding the bone) to fit the implant during surgery. By the use of 3D printer there is a possibility to print patient specific implants with accurate dimensions fitting. Localized production made easy. Implants can be made in house at the hospitals. It is convenient to produce the patient specific implants [23]. The MRI scan and CT scan data can be converted into a 3D model using the available software's like Materialize mimics, Osirix (Mac only), Invesalius, 3D slicer, Seg3D, ImageVis 3D and 3D Doctor. Any part of a human system can be converted into a 3D model $[24,25]$.

The limitations in conventional manufacturing methods of implants for biomedical applications are difficulty in synthesizing complex structures, creating a single object with multi materials, controlling the mechanical properties and maintaining the sterile property of medical implants gives a search of new technology. Thus, advanced technique in manufacturing like AM technology (3D Printing) is adopted [26]. However, the complex shaped nanocomposite producing through 3D Printing requires more time, post processing techniques, high production cost and gives a product with certain poor mechanical properties [27]. Therefore, it is necessity to bring advancement in this AM technology to address these issues. Many types of additive manufacturing techniques are adopted, namely fused deposition modelling (FDM), stereolithography (SLA) and Inkjet 3D printing. Current advanced techniques like Electron Beam Melting (EBM) Direct Metal Laser Sintering (DMLS), Selective Laser Melting (SLM) and Selective Laser Sintering (SLS) were used in medical applications [28,29].

\section{ADDITIVE MANUFACTURING TECHNIQUES USED IN MEDICAL APPLICATIONS \\ 2.1 Fused Deposition Modeling}

The technology Fused deposition modelling is otherwise termed as Fused filament fabrication was invented by Scott Crump in the year 1980 [30].The most common method used in 3D Printing is fused deposition modeling. Fused deposition modeling is non-subtractive manufacturing process. This process uses a biocompatible and biodegradable polymer filament by first fusing it into the semisolid state and then printing a 3D object in a layer by layer process. The schematic view of the process isshown in Figure 1. The widely used materials in fusion deposition modeling (FDM)are acrylonitrile butadiene styrene (ABS), polylactic acid (PLA), polycaprolactone (PCL), polyethylene (PET), polymethyl methacrylate (PMMA), thermoplastic urethane (TPU), Nylon, thermoplastic elastomers (TPE), polyvinyl alcohol (PVA), high density polyethylene (HDPE) and high impact polystyrene (HIPS) [31]. Carbon filled with ABS/ PLA/ TPU/ TPE/ HDPE/HIPS filaments is also being researched nowadays to get a higher tensile/ compressive strength in dental and orthopedic prosthetics.

The filaments being used in fused deposition modeling (3D Printing) can be made as nanocomposite materials. The preparation of nanocomposite filaments is complicated as it requires an additional device named filament extruder machine [32]. The process needs engineering optimization to get a filament with an accuracy of $1.75 \mathrm{~mm}$ diameter which can be used as filament in 3D Printers [33]. However, getting the desired diameter is a complicated process which includes optimization of many parameters such as melting temperature of the nanocomposite mixture, speed of the conveyor screw, ratios of nanocomposite ingredients and nozzle diameter of the extruder [34].

Fused deposition modeling process itself needs an optimization of printing speed, nozzle temperature, hot bed temperature, layer thickness and the nozzle size to be used. Printing a nanocomposite filament using 3D Printer (FDM) is a very tough and complicated work [35]. The 3D printed objects need post processing such as grinding, polishing and finishing. Producing a hierarchically structured nanocomposite using FDM is a complicated process and its need more attention to avoid damage of FDM machine because during its operation the temperature setting may range from $70^{\circ} \mathrm{C}$ to $220^{\circ} \mathrm{C}$ with respect to the type of constituent materials in the filament[36]. Hierarchical nanocomposite implants are best suited to the human system as it resembles the same structure. Nanocomposite material for implants in dental and orthopedics can be obtained by printing a single polymer and then processing the printed material with some other process such as electro spinning and electro spraying [37]. These combinational approaches are required if single polymer filament is used in FDM. Electrospinning/electrospraying is a strategy which involves the fluid atomization by electrical force to make them into a continuous nano fiber/ droplets respectively. Nano fibers/ droplet size can be altered by electrical charge and flow rate. These approaches also require process optimization.

\subsection{Direct Ink Writing}

Robocasting or Direct ink writing is developed by Sandia National Laboratories in 1996. Direct ink writing involves printing of ink or hydro-gel into a 3D motif with the aspect size ranging from $100 \mathrm{~nm}$ to $1 \mathrm{~mm}$ [38]. The 3D scaffold model will be converted into a layer-by-layer object using computer aided software's [39].A line diagram shows the direct ink writing method in Figure 2.The working set up consist of solid platform on which the ink will be printed, cylindrical nozzle using which the ink pass through for getting printed, and an optical microscope which is used for monitoring the printing process. The diameter of the nozzle affects the air pressure and speed of printing [40]. The hydro-gels used in this technique can be a pure hydro-gel or nanoparticle filled hydro-gel or organic hydro-gels. The pure hydrogels, however have certain drawbacks of poor mechanical stability and can be easily degraded. The hydro-gels used in this technique should mainly possess controlled property of viscosity and elasticity [41]. In case of nanoparticle filled hydro-gels there should be $70-85 \%$ of solid filling in order to avoid spreading of the ink during extrusion. In order to overcome the demerits of pure hydrogels important advances has been done by using various hydro-gel composites which are seen to possess desired mechanical property [42]. 


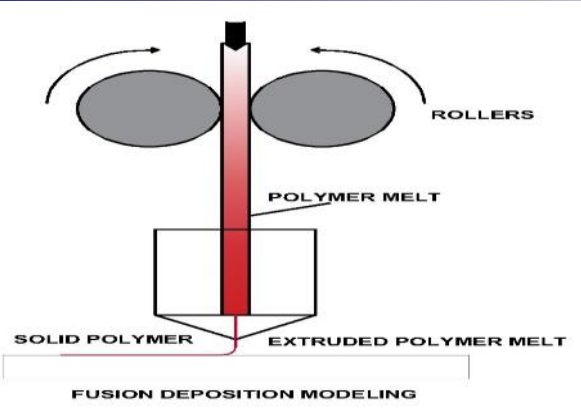

Figure 1. Fusion Deposition Modeling

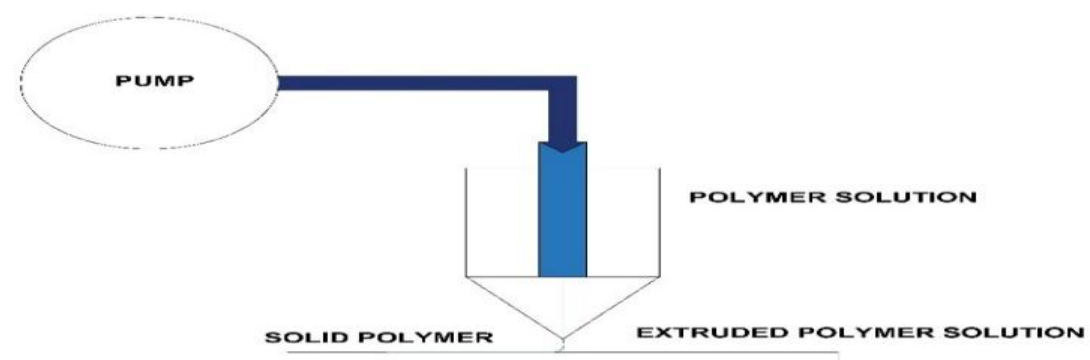

DIRECT INK WRITING

Figure 2. Direct Ink Writing

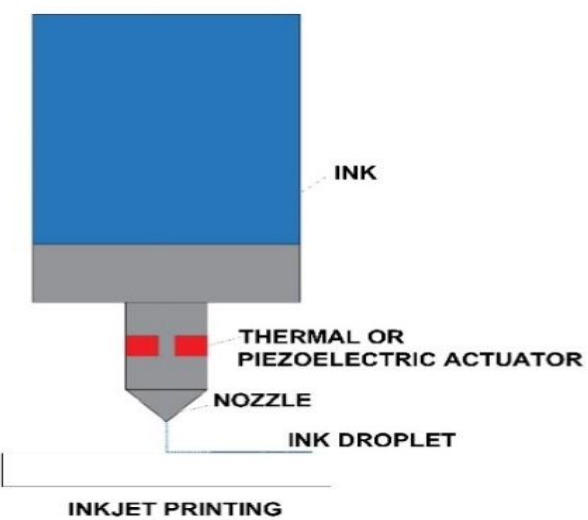

Fig. 3. Inkjet Printing

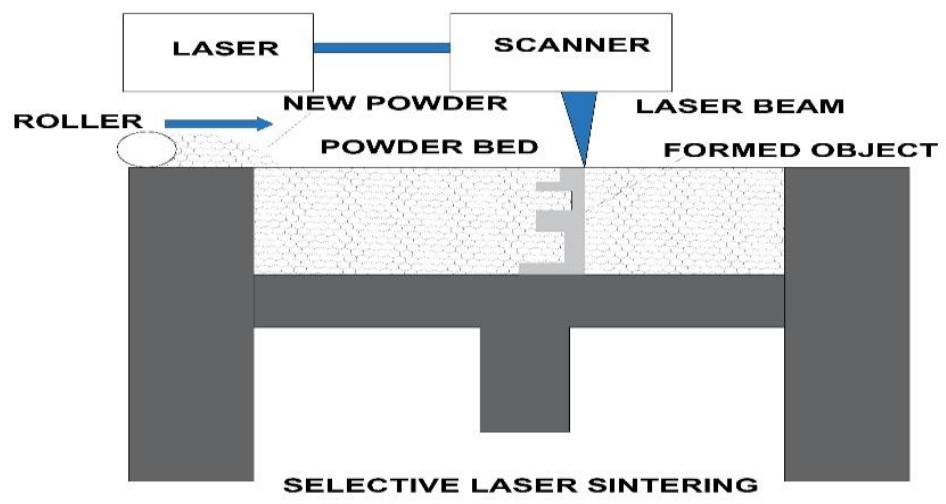

Fig. 4 Stereolithography

Dinesh Babu \& Devaprakasam 


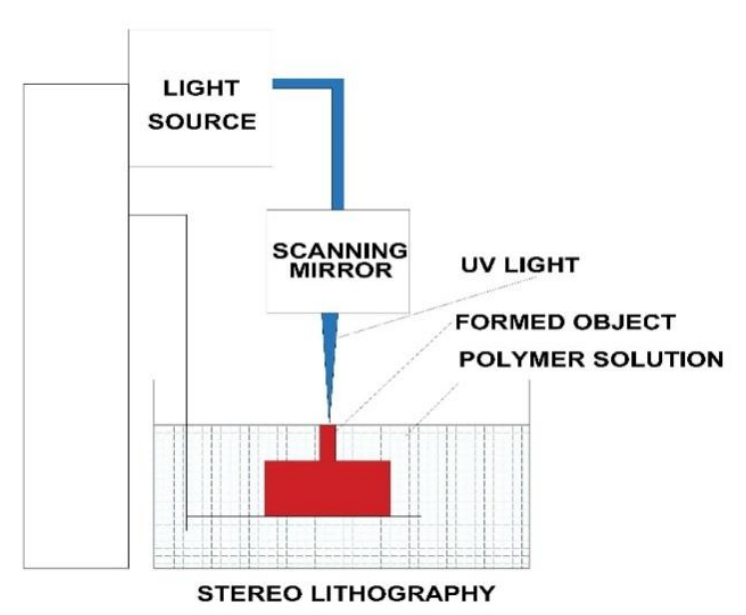

\subsection{Inkjet Printing}

Inkjet printing was first invented by Lord Kelvin (William Thompson) in the year 1867; it was further developed by a company Siemens for advanced applications in the medical industry. Inkjet printing process of AM is characterized by a sudden pressure in the nozzle which results in the formation of droplets and the drops get positioned on the substrate in a jet like manner. The ink formulations generally consist of nanomaterials dispersed in either a single solvent or mixture of solvents [43]. Working methodology shown in Figure 3. Nano ceramic powders can be used in inkjet printing by adding with distilled water. Proper printing of the ink is based on its stability, surface tension, shear thinning and drying property. The range of layer thickness of the objects obtained through inkjet printing fall between $100 \mathrm{~nm}$ and few $\mu \mathrm{m}$ [44]. Design of flexibly thin and transparent substrate can be obtained using inkjet printing.

Based on the process of droplet formation there are two distinguished types of inkjet printer. In one case the electric voltage is applied to create heat that makes the solvent to boil which then results in the formation of pressure. This type is called a thermal inkjet printer. The other one is a piezoelectric inkjet printer. In this type the piezo element in the nozzle wall will undergo shape change induced by pressure caused by electric voltage. In both the types the ejection speed of the printing is based on the intensity and the time duration of voltage pulses [45].

Nowadays, inkjet printing has been applied in the synthesis of biomaterials, 3D cell structures for tissue engineering and functional ceramics due to its low-cost processing, flexibility and easy to use properties. The main disadvantage of inkjet printing is that, it can't be used in the mass industrial process due to its slow process speed and non-compatible in the large substrate productions. The currently available mechanism used in Inkjet printing is continuous inkjet printing (CIJ), drop-on-demand (DOD), and electrostatic inkjet printing (EIJ). In CIJ there is possibility of ink wastage and there is a need of recirculation. Most of the published work uses the DOD technology as it has less wastage in inks and easy to

\section{aser Sintering}

fabricate ceramic coated layers. EIJ requires inks, which are conductive materials. Since there is a limitation in EIJ, CIJ and DOD are the most used technology over 40 years [46].

\subsection{Stereolithography}

The term Stereolithography (SLA) was coined by Charles W. Hull in the year 1986 [47]. In short Stereolithography is called as SLA which involves synthesis of 3D objects through a step-wise manner using a fluid medium and involves a particular simulation which results in consecutive structural modification. Line diagram of this process is shown in figure 4. Like other AM techniques, SLA uses computer-aided design for the synthesis of implants. The implant structures are synthesized in a layer-by-layer process with the thickness ranging between $25 \mu \mathrm{m}$ to $100 \mu \mathrm{m}$. The precision of the synthesis is monitored by computer-controlled process. The stereolithography method of the AM have some parameter optimization needs to be carried out to get a solid object without any faults. The solidification of the composite resin occurs by spatially controlled polymerization using digital light source [48].

SLA plays a major role in tissue engineering, especially in bone repairs due to its greater structural resolution property. Design and shape of the bioimplants can be better achieved. There could be an advantage in case of high control over the micro and macro structures, pore size and percentage of porosity. Since SLA uses clinically scanned data, it is very much useful in the synthesis of patient specific implants or replica of human body parts, drill guides, moulds for implants and scaffold for tissue engineering. Thus, it plays a major role in oral and CranioMaxillofacial surgeries [49].

\subsection{Selective Laser Sintering}

This process was first fabricated and patented by Carl Deckard in 1989 [50]. Selective laser sintering is the process of direct formation of compact mass or solid structure from mostly a powdered material using a laser as a heat source. Like other AM techniques, SLS also make use computer aided design (CAD) model for producing a multiplex structure within no time. First the model file is examined and fragmented into cross sections with

\section{Dinesh Babu \& Devaprakasam}


thickness of $<0.25 \mathrm{~mm}$. The fine powder with which the compact mass going to be built is first spread on the moveable platform by a feed- and roller- apparatus. Now the laser is used to sinter the powder into a compact mass. The thickness of the layers of this solid mass will be the same as that of cross sections of the model. Then this solid mass is covered by a new film by powder material to repeat the same process till complete shape of the model is fabricated [51]. Schematic view of the process is shown figure 5 .

The important advantage of SLS is that layer porosity percentage, interconnectivity of pores, size and shape can be controlled by altering the size of the powder particles, layer thickness, scan speed and spot diameter of the laser beam. Thereby we can control the architecture of fabricated objects. Only industrial scale SLS are available in the market, so lead time is longer than other 3D printing techniques like FDM and SLA. Post processing is required for porous and grainy structures. After the sintering process may result in wraps surface, hence large flat surface cannot be produced using SLS [52].

3. MANUFACTURING OF POLYMER NANOCOMPOSITES : CONVENTIONAL AND ADDITIVE MANUFACTURING

Pre-processing or post processing is required to manufacture polymer nanocomposites using 3D Printing (AM) techniques like FDM, SLA. A filament extruder (single screw or twin-screw type) is required to mix the nanocomposite materials to form a filament to be used in FDM. Ultrasonication is required for SLA processing. Ultrasonication is used to mix the multiple materials thoroughly to form a homogenous mixture of liquid. This liquid can be used in SLA [53].

Table 1. Physical/Mechanical and biological properties of Polymer Nanocomposite

\begin{tabular}{|c|c|c|c|c|c|c|c|}
\hline \multirow[b]{2}{*}{$\begin{array}{l}\text { Sl. } \\
\text { No }\end{array}$} & \multirow[b]{2}{*}{$\begin{array}{c}\text { Polymer } \\
\text { Nanocomposite }\end{array}$} & \multirow[b]{2}{*}{ Method } & \multicolumn{3}{|c|}{ Mechanical Properties } & \multirow[b]{2}{*}{$\begin{array}{l}\text { Biological } \\
\text { Properties }\end{array}$} & \multirow[b]{2}{*}{ Reference } \\
\hline & & & $\begin{array}{l}\text { Youngs } \\
\text { Modulus } \\
\text { (MPa) } \\
\end{array}$ & $\begin{array}{c}\text { Compressive } \\
\text { Strength } \\
\text { (MPa) }\end{array}$ & $\begin{array}{c}\text { Flexural } \\
\text { Strength } \\
\text { (MPa) }\end{array}$ & & \\
\hline 1 & $\begin{array}{c}\text { Calcium Phosphate- } \\
\text { Poly L } \\
\text { Lactic Acid (PLLA) }\end{array}$ & FDM & $13.2 \pm 0.3$ & $1.12 \pm 0.05$ & - & $\begin{array}{c}\text { Osteoconductivity } \\
\text { and } \\
\text { Osteoinductivity }\end{array}$ & {$[57]$} \\
\hline 2 & $\begin{array}{c}\text { Propylene fumarate } \\
\text { dimethacrylate } \\
\text { (PFDMA) infill+PLA } \\
\text { shell } \\
\end{array}$ & SLA & 100 & 10 & - & $\begin{array}{l}\text { Biocompatibility } \\
\text { and } \\
\text { Osteoconductivity }\end{array}$ & {$[58]$} \\
\hline 3 & PLA-graphene & FDM & 146 & - & - & - & [59] \\
\hline 4 & PLA/gelatin-forsterite & FDM & $170 \pm 13.9$ & - & - & $\begin{array}{c}\text { Bioactivity } \\
\text { (Biocompatibility) }\end{array}$ & {$[60]$} \\
\hline 5 & $\begin{array}{c}\text { Poly (lactic acid) } \\
\text { /hydroxyapatite }+ \\
\text { glycidyl } \\
\text { methacrylate }+ \text { dicumyl } \\
\text { peroxide } \\
\end{array}$ & FDM & - & - & 86 & $\begin{array}{c}\text { Biocompatibility } \\
\text { and } \\
\text { Biodegration }\end{array}$ & {$[61]$} \\
\hline 6 & $\begin{array}{c}\text { Ti+bisphenol F (BPF) } \\
\text { epoxy resin }\end{array}$ & - & $16.6 \pm 1.5$ & & & Osteointegration & {$[62]$} \\
\hline 7 & $\begin{array}{l}\text { Polycaprolactone } \\
\text { /Hydroxyapatite }\end{array}$ & - & $241.6 \pm 12$ & $19 \pm 0.4$ & & Biocompatibility & {$[63]$} \\
\hline 8 & $\begin{array}{c}\text { Poly(c-caprolactone)/ } \\
\text { Hydroxyapatite/ } \\
\text { Poly Propylene } \\
\text { Fumarate } \\
\text { (PCL/Hap/PPF) }\end{array}$ & FDM & $33.74 \pm 1.08$ & - & - & $\begin{array}{l}\text { Degradation and } \\
\text { Biocompatibility }\end{array}$ & {$[64]$} \\
\hline 9 & $\begin{array}{c}\text { Polyetheretherketone } \\
\text { (PEEK) + } \\
\text { hydroxyapatite } \\
\text { (HAP) + Graphene } \\
\text { oxide (GO) }\end{array}$ & - & - & 65.41 & - & $\begin{array}{l}\text { Biocompatibility } \\
\text { and } \\
\text { Osteointegration }\end{array}$ & {$[65]$} \\
\hline 10 & $\begin{array}{l}\text { Calcium sulfate-based } \\
\text { hydroxyapatite }+\varepsilon- \\
\text { polycarbonate }\end{array}$ & FDM & & $87.96 \pm 6.05$ & & $\begin{array}{l}\text { Biocompatibility } \\
\text { and } \\
\text { Biocompatibility }\end{array}$ & {$[66]$} \\
\hline 11 & $\begin{array}{c}\text { PCL-PEG-PCL } \\
\text { copolymer }\end{array}$ & - & 349 & - & - & Biocompatibility & {$[67]$} \\
\hline 12 & PCL/HAp & - & 350 & - & - & Biocompatibility & [68] \\
\hline
\end{tabular}


In FDM the parameters need to be studied and optimized to get a proper printed material. Optimization avoids nozzle clogging, an agglomeration of a particle at the same place, irregular object shape. In SLA process parameters like base exposure time, base exposure time, resolution and operating temperature. The materials used in SLA are limited to polymer resins, nanoceramics can be used with the polymer resins to produce bionanocomposite implants. Conventional manufacturing methods also used to produce bio-nanocomposite for implantation. Some of the conventional manufacturing methods are (i) Intercalation method, (ii) In situ Polymerization, (iii) Sol Gel method and (iv) Direct mixing of polymer and Nanofillers [54].

The intercalation process generally dissolving of nanoplatelets of nanomaterials into the polymer matrix. The dispersion of nanomaterials into polymer matrix will enhance the mechanical properties like stiffness, surface hardness, strength, etc. Melt interaction is a common technique used to make polymer composite. The polymer will be molted till its reach's critical temperature in a hot plate stirrer then the nanofiller is added to the molten polymer. Then the molten liquid is allowed to cool at normal air temperature to get the polymer matrix nanocomposite.

In situ polymerization, the nanomaterials are synthesized in the presence of polymer networks. Both polymer matrix and nanomaterial are dissolved in aqueous solution and gel is generally refluxed at a high temperature. Decomposition of polymer is a main drawback when processing at higher temperature.

In Sol-Gel method colloidal suspension were formed by the breakup of solid nanomaterials (sol) in monomer solution. Due to polymerization processes monomers were combined to form a continuous network of polymer (Gel). Nanomaterials is interconnects with the network of polymers and thus forms polymer nanocomposites.

Direct Mixing of polymers and Nanofillers, this process involves dissolving of polymers and nanomaterials using solvents. Both the polymer and nanomaterial are dissolved in the same liquid. The liquid is then heated to a certain temperature to make it as solid polymer nanocomposite [55].

\section{MECHANICAL PROPERTIES OF CORTICAL AND CANCELLOUS BONE}

The mechanical properties of the implantable biomaterial play a major role in bringing the long-term life of the implant. Implant material bears the load after implantation. Anticorrosive property of the material gives high reliability to the patient safety because the implant material should not produce toxic wore powders after implantation. Focusing on the mechanical property is an important criterion in biomaterial research. When comparing the cortical and cancellous bones in the human system to the commercially available bone implant materials, mechanical properties of the implants are not meeting the desired standards. So, finding a new biomaterial or developing a novel bio-nanocomposite is obligatory in the future research. Selected mechanical properties of human bone and processed bionanocomposites were briefed in the Table 1 and 2 respectively.

\section{COMMERCIALLY AVAILABLE 3D PRINTED BIO NANOCOMPOSITES}

There are so many companies selling bionanocomposite implants for the medical applications. Some of the well-known companies with their product details are listed in Table 3.

\section{THE FUTURE OF 3D PRINTING IN THE MEDICAL FIELD}

Additive Manufacturing is utilized in bioprinting. Bioprinting is a process of printing living tissues layer-bylayer using 3D Printers which is controlled by computer program system for creating 3D tissue. The living tissues such as heart valves, ears, bone fillings, were printed with a possible successive rate. At present, so many researches were being conducted at the advanced level to create artificially bio-printed living organs such as kidney, liver, pancreas and so on [69]. It is projected that additive manufacturing will cut the cost of surgery by pre planning the surgical site using additively manufactured models and producing implants with low manufacturing cost. Onsite cell printing research is now being carried out to develop skin implantation and bone tissue engineering. 3D Printing in spine surgery is very limited and it is developing gradually.

Many researchers have been started all over the world to manufacture 3D printed medical devices, surgical models, implants, surgical guides, etc. With the application of $3 \mathrm{D}$ bioprinting it is possible to mimic a biological system and make as implant and thus it helps in printing organs externally. 3D bioprinting plays a game changer in cardiac medicine. Now it is possible to print heart valves which can implanted using surgery. 3D Printing of organs and tissue cells ensures the patient stability after surgery helps in boosting the acceptance ratio with patient body and also reduces the cost of treating the associated diseases [70]. It is not sure all the time patients will be available to educate medical students there is a need of models to study the anatomy of humans here the 3DPrinting is used.

Table 2 Mechanical properties of Human Bone [56].

\begin{tabular}{|c|c|c|c|}
\hline $\begin{array}{c}\text { Sl. } \\
\text { No }\end{array}$ & Property & $\begin{array}{c}\text { Cortical } \\
\text { bone }\end{array}$ & $\begin{array}{c}\text { Cancellous } \\
\text { bone }\end{array}$ \\
\hline 1 & Compressive strength/MPa & $100-230$ & $2-12$ \\
\hline 2 & Flexural, tensile strength/MPa & $50-150$ & $10-20$ \\
\hline 3 & Young's modulus/GPa & $7-30$ & $0.5-0.05$ \\
\hline
\end{tabular}

Dinesh Babu \& Devaprakasam 
Table 3 List of 3D Printed biomedical products available in the market.

\begin{tabular}{|c|c|c|c|c|}
\hline $\begin{array}{l}\text { Sl. } \\
\text { No. }\end{array}$ & Name of Company & Product Name & Material & Applications \\
\hline 1 & $\begin{array}{l}\text { Johnson and Johnson } \\
\text { (DePuy Synthes) }\end{array}$ & TRUMATCH® & 3D Printed Titanium & $\begin{array}{c}\text { Craniomaxillofacial } \\
\text { implants }\end{array}$ \\
\hline 2 & $\begin{array}{l}\text { Johnson and Johnson } \\
\text { (DePuy Synthes) }\end{array}$ & ACTIS $®$ & $\begin{array}{c}\text { Hydroxyapatite (HA) } \\
\text { coated on stainless steel }\end{array}$ & Total Hip Replacements \\
\hline 3 & $\begin{array}{l}\text { Johnson and Johnson } \\
\text { (DuPuy Synthes) }\end{array}$ & CORAIL® & $\begin{array}{l}\text { HA coated cementless } \\
\text { implant }\end{array}$ & $\begin{array}{l}\text { Total Hip revision } \\
\text { Surgery }\end{array}$ \\
\hline 4 & Zimmer Biomet & & & Dental Implants \\
\hline 5 & Stryker & Anato & $\begin{array}{l}\text { Hydroxyapatite coated } \\
\text { stainless steel }\end{array}$ & $\begin{array}{l}\text { Femoral hip } \\
\text { replacements }\end{array}$ \\
\hline 6 & Stryker & ReUnion RFX & $\begin{array}{c}\text { Polyethylene titanium 3D } \\
\text { implants }\end{array}$ & $\begin{array}{l}\text { Femoral hip } \\
\text { replacements }\end{array}$ \\
\hline 7 & Osteomed & OsteoVation & Calcium Phosphate & Bone filling applications \\
\hline 8 & Osteomed & $\begin{array}{l}\text { DBM Cancellous } \\
\text { Sponges }\end{array}$ & Porous Sponge biomaterial & $\begin{array}{l}\text { trabeculae bone filling } \\
\text { equipment used with } \\
\text { filling agents }\end{array}$ \\
\hline 9 & Medtronic & Tribal Tray® & $\begin{array}{l}\text { Cobalt chromium } \\
\text { molybdenum, biopolymer }\end{array}$ & Total knee arthroplasty \\
\hline 10 & Medtronic & TiONIC(TM) & Titanium 3D implants & Spine Surgery Implants \\
\hline
\end{tabular}

The market predicted in India is to rise for 3DPrinting with the applications in medicine, aeronautics, research and development groups, manufacturing sectors, also in defense, etc. Future advances in implementing 3DPrinting technology in medical on-site for the recovery of damaged cells, tissues such as muscles, arteries, and nerves etc., Spine replacement surgery made easy with the application of 3D printing [71]. High accuracy, cost effectiveness, less operative time which gives speedy recovery are the most important things that 3D Printing gives to medicine field [72].

\section{CHALLENGES IN ADDITIVE MANUFACTURING}

In future medical experts and AM researchers have to work together to commercialize the additively manufactured implants. In trauma care there is need of urgency to make patient specific implants to be implanted [73].Multidisciplinary research is required in this additive manufacturing of bio-nanocomposite for biomedical applications. AM processes is slow, when it is used in trauma care the AM cannot be a successful player when there is urgency raised. AM processes should be speeded up in the future to avoid these complications. There is a possibility of copyright infringements due to 3D Printing processes anyone can make a duplicate of a product without getting proper copyright [74]. The food and drug administration (FDA - USA) have given some technical considerations for additively manufactured medical devices in the year 2017 [75]. So far, the FDA has approved very few implants for the use in medical applications. 3D Printing can be a threat to manufacturing jobs, it can reduce the process for manufacturing complex structures thus many people may lose their jobs. 3D
Printing processes require skilled operators and it should be operated with precautions. The material used in 3D Printing should be biodegradable and recyclable, otherwise it may lead to the formation of huge waste and will pollute the environment.

\section{CONCLUSION}

In this review, recent trends on the various processing methods of polymeric, ceramic and metallic bionanocomposite using AM and conventional methods were briefed. Every method in AM has its own limitation with respect to their process parameters. Polymer bionanocomposites processing techniques is having few limitations when compared to other bio-nanocomposites. However, the physical and mechanical properties of polymer bio-nanocomposites does not compete with other bio-nanocomposites. Number of researches on metallic and ceramic bio-nanocomposites are very limited due to their expensive processing techniques. Further investigations need to be done to synthesis desired polymer nanocomposite in a cost-effective way.

\section{ACKNOWLEDGEMENT}

The authors wish to thankfully acknowledge the Management of VIT University, Chennai Campus for their constant encouragement and support to the finishing of this review work. The authors also acknowledge Rajiv Gandhi College of Engineering and Technology (RGCET), Puducherry and InCUBE-EngSciRes RandD, Udumalpet, Coimbatore, for providing technical and financial support to carry out this work.

\section{Dinesh Babu \& Devaprakasam}




\section{REFERENCES}

[1]. Syed, A.M, Elias, P. K., Amit, B., Susmita, B., Lisa O., Costas, C., 2018. Additive manufacturing: scientific and technological challenges, market uptake and opportunities. Materials Today, 21, 22-37.

[2]. Asaad, F., Pagni, G., Pilipchuk, S.P., Giannì, A.B., William V. Giannobile, and Rasperini, G., 2016. 3DPrinted Scaffolds and Biomaterials: Review of Alveolar Bone Augmentation and Periodontal Regeneration Applications. International Journal of Dentistry. 2016, 1-15.

[3]. Qian, Y., Hanhua, D., Jin, S., Jianhua, H., Bo, S., Qingsong, W., Yusheng, S., 2018. A Review of 3D Printing Technology for Medical Applications. Engineering, 4, 729-742.

[4]. Kwon, H.I., Kim, S.H., Park, J.S., and Hong, M.G., 2017. A Study on Business Ecosystem of 3D Printing Contents Distribution Platform: Using Service Value Network Analysis. International Journal of Applied Engineering Research, 12, 15580-1559.

[5]. http://www.grandviewresearch.com/industryanalysis/3d-metal-printing-market. Retrieved 18/12/2018.

[6]. Ghosh, S.B., 2008. Bone as a Collagenhydroxyapatite Composite and its Repair. Trends in Biomaterial and Artificial Organs, 22, 116-124.

[7]. Eliaz, N., and Metokim N., 2017. Calcium Phosphate Bioceramics: A Review of Their History, Structure, Properties, Coating Technologies and Biomedical Applications. Materials, 10, 1-104.

[8]. Palmer, L.C., Newcomb, C.J., Kaltz, S.R., Spoerke, E.D., and Stupp, S.I., 2008. Biomimetic systems for hydroxyapatite mineralization inspired by bone and Enamel. Chemical Reviews, 108, 4754-4783.

[9]. Yang, X., Li. Y., Lemaire, A., Yu, J., and Su, B., 2009. Hierarchically structured functional materials: Synthesis strategies for multimodal porous networks. Pure Appl. Chem., 81, 2265-2307.

[10]. Duraccio, D., Mussano, F., Faga, M.G., 2015. Biomaterials for dental implants: current and future trends. Journal of Material Science, 50, 4779-4812.

[11]. Tayebi, T., and Moharamzadeh, K., 2018. Biomaterials for Oral and Dental Tissue Engineering. Woodhead Publications, pp. 525-542.

[12]. Chen, Q., Thouas. G., 2015. Metallic implant biomaterials. Material Science and Engineering R, 87, 1-57.

[13]. Mantripragada V.P., Lecka-Czernik, B., Ebraheim, N., and Jayasuriya, A., 2013. An overview of recent advances in designing orthopedic and craniofacial implants. Journal of Biomedical Material Research Part A, 101, 3349-3364.

[14]. Gordeev, E.G., Galushko, A.S., Ananikov V.P., 2018. Improvement of quality of 3D printed objects by elimination of microscopic structural defects in fused deposition modeling. PLoS ONE. 13, e0198370.
[15]. Martinez-Marquez, D., Mirnajafizadeh, A., Carty, C.P., Stewart, R.A., 2018. Application of quality by design for 3D printed bone prostheses and scaffolds. PLoS ONE 13, e0195291.

[16]. Fahmy, M., Jazayeri, H., Razavi, M., Masri, R., Tayebi, L., 2016. Three-Dimensional Bioprinting Materials with Potential Application in Preprosthetic Surgery. Journal of Prosthodontics, 25, 310-318.

[17]. Yanga, G., Li. X., Hea, Y., Maa, J., Ni, G., Zhou, S., 2018. From nano to micro to macro: Electrospun hierarchically structured polymeric fibers for biomedical applications. Progress in Polymer Science, 81, 80-113.

[18]. Greer, J., and Park, J., 2018. Additive Manufacturing of Nano- and Microarchitected Materials. Nano Letters, 18, 2187-2188.

[19]. An, J., Teoh, J., Suntornnond, R., Chua, C., 2015. Design and 3D Printing of Scaffolds and Tissues. Engineering, 1, 261-268.

[20]. Haleem, A., and Javaid, M., 2018. Role of CT and MRI in the design and development of orthopaedic model using additive manufacturing, Journal of Clinical Orthopedics and Trauma, 9, 213-217.

[21]. Venuvinod, P., Ma W., 2004. Rapid Prototyping Laser based and Other Technologies. Springer Publications, Boston, MA, pp. 135-194.

[22]. Vukicevic, M., Mosadegh, B., Min, J., and Little, S., 2017. Cardiac 3D Printing and its Future Directions, JACC: Cardiovascular Imaging, 10, 171184.

[23]. Hoang, D., Perrault, D., Stevanovic, M., and Ghiassi, A., 2016. Surgical applications of three-dimensional printing: a review of the current literature \& how to get started, Annals of Translational Medicine, 4,1-19.

[24]. Chena, X., Possela, J., Wacongnea, C., Ham, A., Klink, P., Roelfsema, P., 2017. 3D printing and modelling of customized implants and surgical guides for non-human primates, Journal of Neuroscience Methods, 286, 38-55.

[25]. Furuhata, T., Song, I., Zhang, H., Rabin, Y., and Shimada, K., 2014. Interactive prostate shape reconstruction from 3D TRUS images, Journal of Computational Design and Engineering, 1, 272-288.

[26]. Mantripragada, V., Lecka-Czernik, B., Ebraheim, N., Jayasuriya, A., 2013. An overview of recent advances in designing orthopedic and craniofacial implants, Journal of Biomedical Materials 101, 3349-3364.

[27]. Chia, H., and Wu, B., 2015. Recent advances in 3D printing of biomaterials, Journal of Biological Engineering, 9, 1-14.

[28]. 3D bio-printing for medical and enhancement purposes: Legal and ethical aspects (2018)www.europarl.europa.eu/RegData/etudes/I DAN/2018/614571/EPRS_IDA(2018)614571(ANN 2)_EN.pdf,

[29]. Low, Z., Chua, Y., Ray, B., Mattia, D., Metcalfe, I., Patterson, D., 2017. Perspective on 3D printing of separation membranes and comparison to related 
unconventional fabrication techniques, Journal of Membrane Science, 523, 596-613.

[30]. Go, J., Hart, A., 2017. Fast Desktop-Scale Extrusion Additive Manufacturing, Additive Manufacturing, 18, 276-284.

[31]. Cicala, G., Latteri, A., Curto, B., Russo, A., Recca, G., and Farè, S., 2017. Engineering thermoplastics for additive manufacturing: a critical perspective with experimental evidence to support functional applications. Journal of Applied Biomaterials and Functional Materials, 15, 10-18.

[32]. Dizon, J., Espera Jr, A., Chen, Q., and Advincula, R., 2018.

Mechanical characterization of 3D-printed polymers. Additive Manufacturing, 20, 44-67.

[33]. Woern, A., McCaslin, J., Pringle, A., Pearce, J., 2018. RepRapableRecyclebot: Open source 3-D printable extruder for converting plastic to 3-D printing filament. HardwareX, 4, 1-58.

[34]. Farahanchi, A., Boehm, E., and Malloy, R., 2017. The Effect of ultra-high-speed twin-screw extrusion on ABS/organoclay nanocomposite blend properties. Polymer Engineering and Science, 57, 60-68.

[35]. Spoerk, M., Gonzalez-Gutierrez, J., Sapkota, J., Schuschnigg, S., \& Holzer, C., 2017. Effect of the printing bed temperature on the adhesion of parts produced by fused filament fabrication. Plastics, Rubber and Composites, 47, 17-24.

[36]. Nadgorny, M., and Ameli, A., 2018.Functional Polymers and Nanocomposites for 3D Printing of Smart Structures and Devices, ACS Applied Materials and Interfaces, 10, 17489-17507.

[37]. Chiara, G., Letizia, F., Lorenzo, F., Edoardo, S., Diego, S., Stefano, S., Eriberto, B., and Barbara, Z., 2012. Nanostructured Biomaterials for Tissue Engineered Bone Tissue Reconstruction. International Journal of Molecular Sciences, 13, 737-757.

[38]. Fedorovich, N., Schuurman, W., Wijnberg, H., Prins, H., Weeren, P., Malda, J., Alblas, J., Dhert, W., 2011. Biofabrication of osteochondral tissue equivalents by printing topologically defined, cell-laden hydrogel scaffolds. Tissue Engineering Part C: Methods 18, 33-44.

[39]. Saleh, M., Hu, C., and Panat, R., 2017. Threedimensional microarchitected materials and devices using nanoparticle assembly by pointwise spatial printing. Science Advances, 3, e1601986.

[40]. Munaz, A., Vadivelu, R., John, J., 2016. Matthew Barton, Harshad Kamble, Nam-Trung Nguyen. Three-dimensional printing of biological matters. Journal of Science: Advanced Materials and Devices. 1, 1-17.

[41]. Jang, T., Jung, H., Pan, H., Han, W., Chen, S., Song. J., 2018. 3D printing of hydrogel composite systems: Recent advances in technology for tissue engineering. International Journal of Bioprinting, 4, 1-28.

[42]. Sivashanmugam, A., Arunkumar, R., Priya, M., Nair, S., Jayakumar, R., 2015. An overview of injectable polymeric hydrogels for tissue engineering. European Polymer Journal, 72, 543-565.

[43]. Gardini, D., Dondi, M., Costa AL., Matteucci, F., Blosi, M., Galassi, C., Baldi, G., Cinotti, E., 2008. Nano-sized ceramic inks for drop-on-demand ink-jet printing in quadrichromy, Journal of nanoscience and nanotechnology, 8, 1979-1988.

[44]. Chen, Z., Li, Z., Li, J., Liu, C., Lao, C., Fu, Y., Liu, C., Li, Y., Wang, P., and He, Y., 2018. 3D printing of ceramics: A review. Journal of the European Ceramic Society, 39, 661-687.

[45]. Eshkalak, S., Chinnappan, A., Jayathilaka, W., Khatibzadeh, M., Kowsari, E., and Ramakrishna, S., 2017. A review on inkjet printing of CNT composites for smart applications, Applied Materials Today, 9, 372-386.

[46]. Derby, B., 2015. Additive Manufacture of Ceramics Components by Inkjet Printing. Engineering, 1, 113-123.

[47]. Elliot, B., Sami, M., Mikhail, P., Hue, L., Michael, L., Jennifer, W., Guillermo, A., Tong, H., Russell, R., 2017. 3-D bioprinting technologies in tissue engineering and regenerative medicine: Current and future trends. Genes \& Diseases, 4, 185-195.

[48]. Zhou, J., Herscovici, D., Chen, C., 2000. Parametric process optimization to improve the accuracy of rapid prototyped stereolithography parts. International Journal of Machine Tools \& Manufacture 40, 363-379.

[49]. Jain, P., Pandey, P., Rao, P., 2009. Selective laser sintering of clay-reinforced polyamide. Polymer Composites 31, 732-743.

[50]. Harun, W., Manam, N., Kamriah, M., Sharif, S., Zulkifly, A., Ahmad, I., Miura, I., 2018. A review of powdered additive manufacturing techniques for Ti-6al-4v biomedical applications. Powder Technology, 331, 74-97.

[51]. Goodridge, R., Shofner, M., Hague, R., McClelland, M., Schlea, M., Johnson, R., Tuck, C., 2011. Processing of a polyamide-12/carbon nanofiber composite by laser sintering. Polymer Testing, 30, 94-100.

[52]. Torres, Y., Sarria, P., Gotor, F., Gutiérrez, E., Peon, E., Beltrána, A., González, J., 2018. Surface modification of Ti-6Al-4V alloys manufactured by selective laser melting: Microstructural and tribomechanical characterization. Surface \& Coatings Technology 348, 31-40.

[53]. Derakhshanfar, S., Mbeleck, R., Xu, K., Zhang, X., Zhong, W., Xing, M., 2018. 3D bioprinting for biomedical devices and tissue engineering: A review of recent trends and advances. Bioactive Materials, 3, 144-156

[54]. Khan, W., Hamadneh, N., Khan, W., 2017. Polymer nanocomposites - synthesis techniques, classification and properties. Paolo Di Sia, One Central Press (Eds), Science and applications of Tailored Nanostructures, pp. 50-67.

[55]. Dinesh Babu, R., Prakash, P., Devaprakasam, D., 2017. Review on emerging applications of nanobiomaterials in dentistry and orthopaedics. 
Trends in Biomaterials and Artificial Organs, 31, 164-171.

[56]. Henkel, J., Woodruff, M., Epari, D., Steck, R., Glatt, V., Dickinson, I., Choong, P., Schuetz, M., Hutmacher, D., 2013. "Bone Regeneration Based on Tissue Engineering Conceptions - A 21st Century Perspective" Bone Research, 1, 216-248.

[57]. Wang, C., Zhao, Q., and Wang, M., 2017. Cryogenic 3D printing for producing hierarchical porous and rhBMP-2-loaded Ca-P/PLLA nanocomposite scaffolds for bone tissue engineering. Biofabrication, 9, 02503.

[58]. Sears, N., Dhavalikar, P., Whitely, M., and CosgriffHernandez, E., 2017. Fabrication of biomimetic bone grafts with multi-material 3D printing. Biofabrication 9, 025020.

[59]. Bustillos, J., Montero, D., Nautiyal, P., Loganathan, A., Boesl, B., and Agarwal, A., 2017. Integration of Graphene in Poly(Lactic) Acid by 3D Printing to Develop Creep and Wear-Resistant Hierarchical Nanocomposites. Polymer composites, 39, 3877 3888.

[60]. Naghieh, S., Foroozmehr, E., Badrossamay, M., Kharaziha, M., 2017. Combinational processing of 3D printing and electrospinning of hierarchical poly (lactic acid)/gelatin-forsterite scaffolds as a biocomposite: Mechanical and biological assessment. Materials \& Design, 133, 128-135.

[61]. Monmaturapoj, N., Srion, A., Chalermkarnon, P., Buchatip, S., Petchsuk, A., Noppakunmongkolchai, W., and Mai-Ngam, K., 2017. Properties of poly (lactic acid)/hydroxyapatite composite through the use of epoxy functional compatibilizers for biomedical application. Journal of Biomaterials Applications. 32, 175-190.

[62]. Okulov V., Weissmüller, J., Markmann, J., 2017. Dealloying-based interpenetrating-phase nanocomposites matching the elastic behavior of human bone. Scientific Reports, 7, 1-7.

[63]. Moeini, S., Mohammadi, M., Simchi, A., 2017. In-situ solvothermal processing polycaprolactone/hydroxyapatite nanocomposites with enhanced mechanical and biological performance for bone tissue engineering. Bioactive Materials 2, 146-155.

[64]. Buyuksungur, S., Tanir, T., Buyuksungur, A., Bektas, E., Kose, G., Yucel, D., Beyzadeoglu, T., Çetinkaya, E., Yenigun, C., Tonuk, E., Hasirci, V., Hasirci, N., 2017. 3D Printed Poly(e-caprolactone) Scaffolds Modified with Hydroxyapatite and Poly (propylene fumarate) and Effects on Healing of Rabbit Femur Defects. Biomaterial Science, 5, 2144-2158.
[65]. Peng, S., Feng, P., Wu, P., Huang, W., Yang, Y., Guo, W., Gao, C., and Shuai, C., 2017. Graphene oxide as an interface phase between polyetheretherketone and hydroxyapatite for tissue engineering scaffolds. Scientific Reports, 7, 46604.

[66]. Kim, B., Yang, S., Park, H., Lee, S., Cho, Y., and Lee, J., 2017. Improvement of mechanical strength and osteogenic potential of calcium sulfate-based hydroxyapatite 3-dimensional printed scaffolds by e-polycarbonate coating. Journal of Biomaterials Science, Polymer Edition, 28, 1256-1270.

[67]. Fu N., Liao, J., Lin, S., Sun, K., Tian, T., Zhu, B., 2016. PCL-PEG-PCL film promotes cartilage regeneration in vivo. Cell Proliferation. 49, 1-11.

[68]. Tong S., Wang, Z., Lim, P., Wang, W., and Thian, E., 2016. Uniformly-dispersed nanohydroxapatitereinforced poly(e-caprolactone) composite films for tendon tissue engineering application. Materials Science and Engineering C. 70, 1149-1155.

[69]. Ratheesh, G., Venugopal, J., Chinappan, A., Ezhilarasu, H., Sadiq, A., and Ramakrishna, S.,2017.3D Fabrication of Polymeric Scaffolds for Regenerative Therapy. ACS Biomaterial Science and Engineering, 3, 1175-1194.

[70]. Paul, G., Rezaienia, A., Wen, P., Condoor, S., Parkar, N., King, W., Korakianitis, T., 2018. Medical Applications for 3D Printing: Recent Developments Missouri medicine. 115, 75-81.

[71]. Gadia, A., Shah, K., and Nene, A., 2018. Emergence of Three-Dimensional Printing Technology and Its Utility in Spine Surgery, Asian Spine Journal, 12, 365-371.

[72]. Diment, L., Thompson, M., and Bergmann, J., 2017. Clinical efficacy and effectiveness of 3D printing: a systematic review, BMJ Open, 7, 1-11.

[73]. Zadpoor, A., 2017. Design for Additive BioManufacturing: From Patient-Specific Medical Devices to Rationally Designed Meta-Biomaterials, International Journal of Molecular Sciences, 18, 118.

[74]. Hornick, J., and Rajan, K., 2015. Intellectual Property in 3D Printing and Nanotechnology, 3D Bioprinting and Nanotechnology in Tissue Engineering and Regenerative Medicine, 16, 349364.

[75]. Technical Considerations for Additive Manufactured Medical Devices (2017). https://www.fda.gov/downloads/MedicalDevices/ DeviceRegulationandGuidance/GuidanceDocument s/UCM499809.pdf,

\section{All (c) 2019 are reserved by International Journal of Advanced Science and Engineering. This Journal is licensed under a Creative Commons Attribution-Non Commercial-ShareAlike 3.0 Unported License.}

